The

\section{Indonesian Wealth}

Buku ini diberi judul The Indonesian Wealth, sebuah buku yang bisa dijadikan pegangan atau rujukan para guru sekolah menengah pertama untuk mengajar Bahasa Inggris. Buku ini disusun menggunakan pendekatan Genre, sebuah pendekatan yang masih dipakai sampai sekarang oleh banyak guru di Indonesia. Dengan sentuhan Linguistik Sistemik Fungsional (LSF), buku ini menyajikan aktivitas pembelajaran yang berpusat pada kemampuan kognitif, afektif, dan juga psikomolorik yang komprehensif. Ada liga jenis leks yang dimual dalam buku ini, yailu teks deskriptif, teks prosedur, dan teks naratif, menyesuaikan dengan kurikulum yang ada untuk sekolah menengah pertama. Setiap teks dijabarkan dengan menggunakan tahapan pada pendekatan genre yaitu Background Knowledge of the Field (BKOF), Modelling, Joint-Construction of the Text (JCOT), dan juga Independent Construction of the Text (ICOT) yang memungkinkan para siswa untuk mengembangkan kemampuan menulis yang baik.

\section{The}

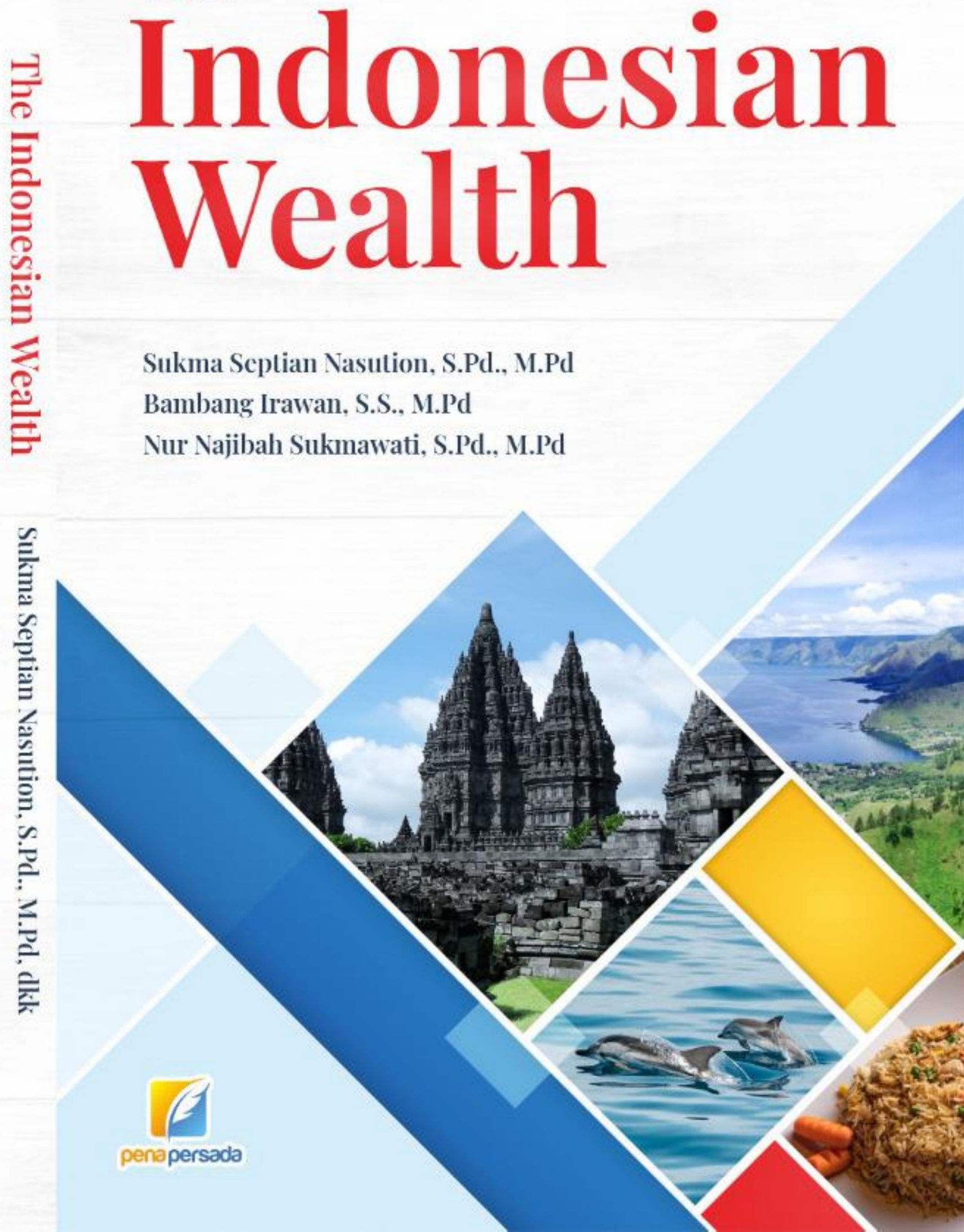




\section{THE INDONESIAN WEALTH}

Sukma Septian Nasution, S.Pd., M.Pd

Bambang Irawan, S.S., M.Pd

Nur Najibah Sukmawati, S.Pd., M.Pd

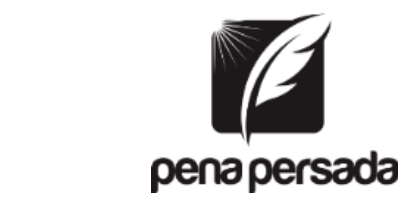

PENERBIT CV. PENA PERSADA 


\title{
THE INDONESIAN WEALTH
}

\author{
Penulis: \\ Sukma Septian Nasution, S.Pd., M.Pd \\ Bambang Irawan, S.S., M.Pd \\ Nur Najibah Sukmawati, S.Pd., M.Pd \\ ISBN : 978-623-315-921-0
}

Design Cover :

Retnani Nur Briliant

Layout :

Eka Safitry

\section{Penerbit CV. Pena Persada}

Redaksi :

Jl. Gerilya No. 292 Purwokerto Selatan, Kab. Banyumas

Jawa Tengah

Email : penerbit.penapersada@gmail.com

Website : penapersada.com Phone : (0281) 7771388

Anggota IKAPI

All right reserved

Cetakan pertama : 2021

Hak Cipta dilindungi oleh undang-undang. Dilarang

memperbanyak karya tulis ini dalam bentuk apapun tanpa izin penerbit 


\section{Preface}

All glory be to Allah Lord of the worlds, the merciful, the beneficent who has bestowed upon us guidance, health, and ability to complete an English book entitled "Learning English through Popular Indonesian Holiday Destinations: Junior High School Edition." The completion of this book aims at empowering English course book for junior high school students. Preparations for this book utilize materials using Genre Based Approach (G.B.A), which is an approach that emphasizes process and production. The Genre Based Approach is a learning method that has four main stages, namely: Building the Knowledge of the Field (B.K.O.F), Modelling of the Text (M.O.T), Joint Construction of the Text (J.C.O.T), and Independent Construction of the Text (I.C.O.T). Through this book, we hope students will be able to learn English effectively and efficiently while enjoying themselves. Furthermore, through this book, we hope to promote the students' creativity and enthusiasm towards learning English. Moreover, we are always open to suggestions and critiques to help improve this book.

South Tangerang, October 4, 2021

Authors 


\section{Table of contents}

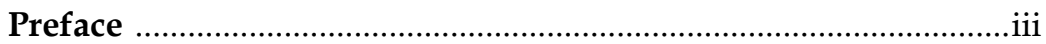

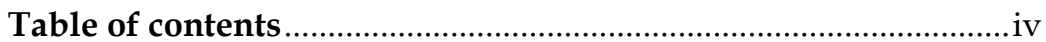

CHAPTER 1 POPULAR TOURISM SPOTS IN INDONESIA ......... 1

A. Language Corner................................................................ 3

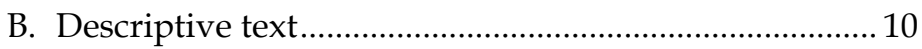

CHAPTER 2 HOW TO MAKE INDONESIAN FOOD ................... 38

A. Imperative Sentence.............................................................. 43

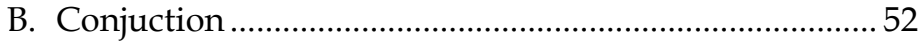

C. Procedure Text.......................................................................... 55

CHAPTER 3 POPULAR INDONESIAN FOLKLORE ………........ 70

A. The Characteristics and Generic Structure of a Narrative Text..................................................................... 70

B. Finding Main Idea............................................................... 78

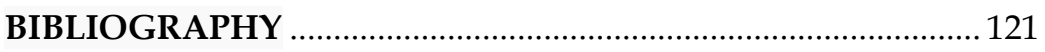




\section{CHAPTER 1 \\ POPULAR TOURISM SPOTS IN INDONESIA}

Objectives: At the end of the lesson, students are able to:

1. Identify the elements of a descriptive text.

2. Analyze and evaluate descriptive texts by conveying moral messages contained in the joint construction and independent construction sections.

3. Create a descriptive text.

\section{Activity 1. Read the sentences below.}

1. There are many tourist attractions in Indonesia that you can visit. How many places have you visited?

2. Have you ever visited a tourist spot that offers cultural values?

3. What do you think of the place?

4. Some of the places also have local wisdom. In Mount Bromo, for instance, there is a terrible history where a slave was declared to be lying and punished. So, be honest with every word you say.

\section{The Beauty of Mount Bromo}

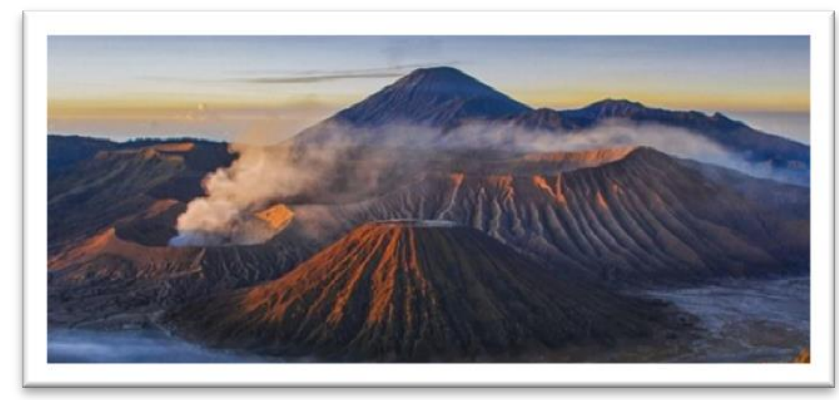

To begin with the formation of lava in the sea with tremendous power, to forming a hole that is getting higher and higher, a beautiful mountain was created. Namely 
Mount Bromo. It is one of the most famous mountains in the world. As one of the typical tourist attractions on the island of Java, we can go to the Mount Bromo every day. It is not only rich with its natural beauty but also with the harmony with the surrounding community.

Mount Bromo also has a fairly strategic location. Located about 2.5 hours from the city of Malang, Bromo is one of the active volcanoes that is part of the Bromo Tengger Semeru National Park. The beauty of Bromo can be seen clearly from the peak of Mount Penanjakan which is close to Bromo and has a higher altitude (2,770 meters). Bromo itself is only 2,392 meters. Even though the Bromo volcano is not very high, the history of its eruptions is dramatic. The expanse of sand around it which people call the sea of sand (segara wedi) is the evidence that this mountain once killed life around it. The name Bromo is taken from the name one of the Hindu gods, namely Brahma.

Finally, the Tenggerese has a myth about the mountain that makes it mystical. But it is more than just a myth as long as people still believe that by holding the Kasada festival every year. They express their gratitude to God symbolically by throwing vegetables, livestock, and also money as offerings at Bromo crater. According to the myth, rain is a good sign if it occurs in the beginning of the year. On the contrary it is a bad sign if it often occurs at the end of an odd year, although it does not always rain here at the end of the year. 


\section{Activity 2. Distinguishing Identification and Description}

Based on the text above, please group the sentences below according to the correct part.

\begin{tabular}{|c|l|l|l|}
\hline No. & \multicolumn{1}{|c|}{ Statements } & IDENTIFICATIONS & DESCRIPTIONS \\
\hline 1 & $\begin{array}{l}\text { Bromo is one of the } \\
\text { most famous } \\
\text { mountains in java. }\end{array}$ & $\boldsymbol{V}$ & $\mathbf{x}$ \\
\hline 3 & $\begin{array}{l}\text { Bromo is not only } \\
\text { mountain but also an } \\
\text { important place. }\end{array}$ & $\begin{array}{l}\text { The beauty of Bromo } \\
\text { can be seen clearly } \\
\text { from the peak of } \\
\text { Mount Pananjakan. }\end{array}$ & $\begin{array}{l}\text { According to the } \\
\text { myth, rain is a good } \\
\text { sign at beginning of } \\
\text { this year. }\end{array}$ \\
\hline 5 & $\begin{array}{l}\text { Bromo itself is only } \\
2,392 \text { meters. Even } \\
\text { the Bromo volcano is } \\
\text { not very high. }\end{array}$ & & \\
\hline
\end{tabular}

\section{A. Language Corner}

1. What are transition signals?

Transition signals are linking words or phrases that connect your ideas and add cohesion to your writing. They signpost or indicate to the reader the relationships between sentences and between paragraphs, making it easier for the reader to understand your ideas. We use a variety of transition signals to fulfil a number of functions. Some of these functions include: to show the order or sequence of events; to indicate that a new idea or an example will follow; to show that a contrasting idea will be presented, or to signal a summary or a conclusion.

2. How are transition signals useful?

Transition signals will:

a. Make it easier for the reader to follow your ideas. 
b. Create powerful links between sentences and paragraphs to improve the flow of information across the whole text. The result is that the writing is smoother.

c. Help to carry over a thought from one sentence to another, from one idea to another or from one paragraph to another.

3. How are transition signals used?

a. Transition signals are usually placed at the beginning of sentences; however, they may also appear in the middle or at the end of sentences.

b. A transition signal, or the clause introduced by a transition signal, is usually separated from the rest of the sentence by commas.

c. You do not need to use transition signals in every sentence in a paragraph; however, good use of transition words will help to make the relationship between the ideas in your writing clear and logical.

Transition signals, also called cohesive devices or conjunctions, are words or phrases that indicate relationships between ideas. There are many different types, the most common of which are described in the next section on transition signals. Some examples of transition signals are: first of all, to begin with (for the beginning of a paragraph or to start a story), then, after that, next (as a continuation of the beginning of a paragraph), finally, in the end (as a closing sign or the end of a paragraph).

\begin{tabular}{|c|c|c|}
\hline Continuation & Reference & Conclusion \\
\hline Before & As for & At least \\
\hline Next & The fact that & Finally \\
\hline Then & Regarding & In the end \\
\hline Afterwards & Speaking about & Eventually \\
\hline Previously & Considering & To conclude \\
\hline
\end{tabular}




\section{Activity 3. Rearranging Paragraphs}

Rearrange paragraphs into cohesive text, paying attention to cue words at the beginning of each paragraph such as First of all, to begin with, even, etc.

1. Afterwards, the natural beauty offered can provide another side of Mount Bromo. The visitors can enjoy the natural beauty as well as the culture in the area. Visitors can use public transportation and even private vehicles. Frequently, visitors take the motorcycle to the Mount Bromo and they continue on foot to the top of the mountain. Bromo is not only a mountain but also an important place for Hindu ritual ceremonies. The ritual starts every Sunday. A caravan of traveler can still follow this traditional ritual with some rules. Usually, they are divided into several groups with different leaders. The community starts by giving offerings in the form of food, livestock and plants, as the sign of a peaceful soul. They do not hunt a flight of birds because this is a symbol of the circle of friends. They also do not damage the tree while still allowing a bunch of plants to thrive to maintain the habitat of a group of insects in their nests.

2. To begin with the formation of lava in the sea with tremendous power, to forming a hole that is getting higher and higher, a beautiful mountain is created namely Mount Bromo. Bromo is one of the most famous mountains in Java in the world. As one of the typical tourist attractions on the island of Java. We can go to the Mount Bromo every day. Mount Bromo is not only rich with its natural beauty but also harmony with the surrounding community.

3. Finally, the Tenggerese have a myth about the mountain that makes it mystical. But it is more than just a myth as long as people still believe that by holding the Kasada festival every year. They express their gratitude to God symbolically by throwing vegetables, livestock, and also money as offerings at Bromo crater. According to the myth, rain is a good sign if it occurs in the beginning of the 
year. On the contrary it is a bad sign if it often occurs at the end of an odd year although it does not always rain here at the end of the year.

4. Then, Mount Bromo also has a fairly strategic location. Located about 2.5 hours from the city of Malang, Bromo is one of the active volcanoes that is part of the Bromo Tengger Semeru National Park. The beauty of Bromo can be seen clearly from the peak of Mount Pananjakan which is close to Bromo and has a higher altitude (2,770 meters). Bromo itself is only 2,392 meters. Even the Bromo volcano is not very high, but the history of its eruptions is dramatic. The expanse of sand around it which people call "the sea of sand" (segara wedi) is evidence that this mountain once killed life around it. The name Bromo is taken from the name of one of the Hindu Gods, namely Brahma.

\section{What is main idea?}

The main idea is the content that is discussed more often in a text. Each paragraph has a main idea that dominates the content so that the reader knows what the author wants to convey in his writing. The main idea is also a sentence, usually placed in the first sentence. However, the main idea can also be placed in the middle or at the end of the paragraph, depending on how the author organizes it. The main idea may not be stated in a sentence which is called unstated main idea. What can be noticed is that the main idea contains topic that is being discussed. Hence, it is called the main idea. 


\section{Activity 4. Finding Main Idea}

Read Mount Bromo again and answer the questions by choosing the correct option.

1. What is the main idea in the first paragraph?

a. The name Bromo is taken from the name of one of the Hindu gods, namely Brahma.

b. Mount Bromo is one of the most famous mountains in Java in the world. As one of the typical tourist attractions on the island of Java.

c. After that, Mount Bromo also has a fairly strategic location.

2. What is the main idea in the second paragraph?

a. Bromo is not only a mountain but also an important place for Hindu ritual ceremonies.

b. Mount Bromo is rich with not its natural beauty but also harmony with the surrounding community.

c. The name Bromo is taken from the name of one of the Hindu gods, namely Brahma.

3. What is the main idea in the third paragraph?

a. Mount Bromo also has a fairly strategic location.

b. To the mystical that rain is a good sign at the beginning of the year.

c. The expanse of sand around it which people call the sea of sand (segara wedi) is evidence that this mountain once killed life around it.

4. What is the main idea in the last paragraph?

a. The Tenggerese have a myth about the mountain that makes it mystical. But it's more than just a myth as long as people still believe that by holding the Kasada festival every year,

b. To begin with the formation of lava in the sea with tremendous power, to forming a hole that is getting higher and higher

c. Even the Bromo volcano is not very high, but the history of its eruptions is dramatic. 


\section{MUSEUM ANGKUT}

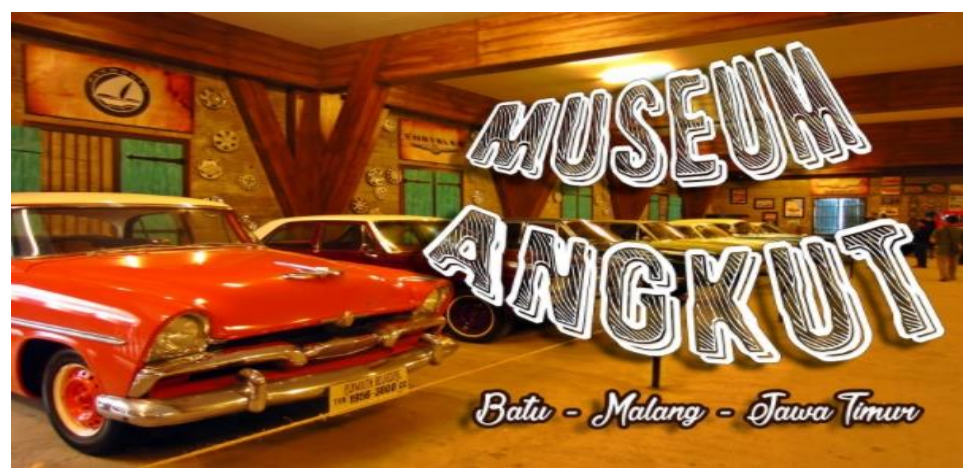

For the people of East Java, Malang is one of the favourite tourist destinations because of its cool natural conditions typical of mountainous areas. Many years ago, Malang was famous as a place for agro tourism and nature tourism, but now tourist attractions in Malang have grown and increased with many modern tourist destinations. The transport museum is one of the modern tourist attractions on the slopes of Mount Panderman. It is located at Jalan Sultan Agung Atas No. 2, Ngaglik Village, Batu City, Malang. Museum Angkut is the most popular tourist attraction in Malang and its surroundings. Museum Angkut combines the concept of entertainment attractions and the history of transportation around the world. This Malang creative museum holds the title as the only tourist spot and the first to carry the concept of transportation tourism in Indonesia. There, visitors can study as well as have recreation while learning about various types of transportation models in Indonesia and around the world.

The City of Batu, Malang Transportation Museum Angkut has a unique but interesting concept to visit when traveling in the city of Malang. Malang does not only rely on natural attractions such as mountains and various Selecta Malang park tours. It turns out that the city of Malang has an interesting museum tourist attraction. The transport museum, 
which was established on March 9, 2014, was built and managed by the Jawa Timur Park Group, which previously built the Batu Secret Zoo, East Java Park I and II, as well as the Batu Night Spectacular, Eco Green Park and the Wildlife Museum. until now this vehicle museum has become a tourist spot that carries the first transportation concept in Southeast Asia.

According to news circulating, the Angkut museum was built as a sign of appreciation for the development of the world of transportation in the archipelago and even the world. Therefore, when visiting the Batu city Angkut museum, you will see various types of vehicles from various brands displayed in the museum room. Many collections of transportation museum vehicles such as transportation that does not use machines or traditional ones such as bicycles, carts, wagons, tricycles to modern vehicles that use electric power are all here. This Malang tourist spot is very interesting to visit, visitors not only see a collection of vehicles from various parts of the world from ancient times to modern times. Visitors are amazed by the various landmark buildings typical of a country as a background for vehicles that produce vehicles, so it feels like traveling around the world.

In Malang Batu Transportation museum area, there are vehicles that have existed from ancient times to those that are often used to travel in various countries. Carrying the environmental concept, this museum is made to almost resemble the country of origin of the vehicle, so that visitors really enjoy the atmosphere of the museum.

The area of the transport museum is approximately 3 hectares, the collection of vehicles in the transport museum is located in each room which is divided into zones on the third floor. When visitors enter Angkut museum building in Batu Malang, they will feel the sensation of a transportation vehicle. If you are a lover of the automotive world, being in this Malang tourist spot will feel like heaven. Not only can you see a collection of various means of transportation from 
around the world, but visitors can also see various replicas of typical landmark buildings from various countries which are the background of the vehicle displays produced by that country. The transport museum is divided into many zones.

\section{B. Descriptive text}

Descriptive Text is a type of text in English that clearly describes the characteristics inherent in something (person, animal, plant or inanimate object). The purpose of this text is to provide clear information about the object described to the reader.

\section{Examples:}

Rose is a plant with enchanting flowers from the genus Rosa which has more than 100 species. This woody perennial plant grows in groups, allowing them to form climbing shrubs with prickles. Rose has various flowers in shapes and sizes, making it one among popular flowering plants found in a house. Most rose species are native to Asia, but some others are native to North America and Europe. It is typically grown for beauty and fragrant. Some species are used for commercial perfumery while some others are cut for ornamental flowers. In addition, rose also has minor medicinal uses.

\section{Language Features of Descriptive Text.}

1. Using Simple Present Tense or Present continuous tense This text uses the Simple Present Tense because we will describe the facts attached to an object, and one of the functions of the Simple Present Tense itself is to show a fact or truth. Suppose you want to describe your bed, you can use the sentence: The color of my bedroom is blue.

2. Using many adjectives (adjectives).

Because the function of this text is to provide information by describing an object being described, in Descriptive Text there will be many adjectives. Examples are big, small, colorful, and so on. 
3. Use connecting verbs.

A relative verb is a verb that gives an explanation to the noun that is the subject of a sentence. For example: is, have, seem, appear, and other verbs.

\section{Generic Structure of Descriptive Text}

Descriptive text has its own rules regarding its structure. The following is the generic structure of descriptive text:

1. Identification

This section, located in the first paragraph, aims to identify an object to be described. Identification serves to introduce the reader to the object that we are going to explain, before we tell about the object in more detail in the next paragraph.

2. Description

This is located in the second paragraph and so on, contains the characteristics inherent in something that you have introduced to the reader in the first paragraph.

\section{Activity 5. Completing the sentences}

Answer the following questions from the text above.

1. Malang is known as a ..... for agro tourism and nature tourism.
a. Place
b. Location
c. Tradition
d. Travel

2. The transport museum is one of the modern ..... attractions on the slopes of Mount Panderman.
a. Place
b. Tourist
c. Location
d. Visitors 
3. .... can study as well as have recreation while learning about various types of transportation models in Indonesia and around the world.
a. Place
b. Tourist
c. Location
d. Visitors

4. What is inside the Transportation museum area?
a. Costume
b. Rocket
c. Old Vehicle
d. New Vehicle

5. Museum Angkut combines the concept of ..... attractions and the history of transportation around the world.
a. Entertainment
b. Tourist
c. Bussiness
d. Visitors

\section{Simple present tense}

Simple present tense is a tense that is used when an event is ongoing or an event that takes place repeatedly (habits). These tenses are tenses that are most often used in English. To form this tense sentence, the basic form of the verb or Verb 1. television is usually used for the third person pronoun, using Verb $1+s / e s$. As shown in the table below.

\begin{tabular}{|c|c|c|}
\hline Subject & Verb & The Rest of the Sentence \\
\hline I/You/They/We & go & to the school by bus \\
\hline She/He/It & goes & to the school by bus \\
\hline
\end{tabular}

$3^{\text {rd }}$ person singular takes an $-\mathrm{s}$ he/she/it + verb $+S$

The form of the verb spelling in the third person (She, He, It), depends on the ending of the verb (verb).

For verbs ending in $-\mathrm{O},-\mathrm{CH},-\mathrm{SH},-\mathrm{X}$, or $-\mathrm{Z}$, add $-\mathrm{ES}$. 


$$
\begin{array}{ll}
\text { go }- \text { goes } & \text { miss }- \text { misses } \\
\text { catch }- \text { catches } & \text { box }- \text { boxes } \\
\text { wash }- \text { washes } & \text { fix }- \text { fixes }
\end{array}
$$

For verbs that end in a consonant $+Y$, omit $Y$, and add -IES.

$$
\begin{array}{ll}
\text { carry }- \text { carries } & \text { in a vowel }+Y, \text { just add }-S . \\
\text { study }- \text { studies } & \text { play - plays } \\
\text { worry }- \text { worries } & \text { say - says } \\
\text { marry }- \text { marries } & \text { enjoy - enjoys }
\end{array}
$$

Meanwhile, for verbs that end

\section{Example of sentences}

To indicate a recurring event that is currently taking place.

1. I take the motorcycle to the office

2. The train to Bekasi leaves every hour.

3. George sleeps seven hours every night during the week.

To show a fact.

4. The President of Indonesia is Joko Widodo.

5. A snake has no legs.

6. Indonesia has thirty-four provinces, from Sabang to Merauke.

To show a habit (habit).

7. Doni gets up early at 5 o'clock every day.

8. John takes a bath twice a day.

\section{Activity 6. Filling in the blanks using Simple Present Tense}

Fill the blanks with the appropriate tenses.

1. For the people of East Java, Malang is (is /are) one of the favourite tourist destinations because of its cool natural conditions typical of mountainous areas.

2. Museum Angkut ...... (combine/ combines) the concept of entertainment attractions and the history of transportation around the world.

3. The transport museum ...... (is/are) one of the modern tourist attractions on the ...... (slope/slopes) of Mount Panderman. 
4. Malang ...... (creative/creatives) museum holds the title as the only tourist spot and the first to carry the concept of transportation tourism in Indonesia.

5. ...... (visitor/visitors) can study as well as have recreation while learning about various types of transportation models in Indonesia and around the world.

6. It ...... (turn/turns) out that the city of Malang has an interesting museum tourist attraction.

7. The area of the transport museum is approximately Three ...... (hectare/hectares).

8. Museum Angkut in Malang East Java, ...... (is/are) the most popular tourist attraction in Malang and its surroundings.

Simple Present Tense Affirmative

To form an affirmative sentence, the formula is

$(S+\operatorname{Verb}(1) /$ Basic verb / to be (is, am, are $)+O)$

Examples of positive simple present tense sentence:

1. Susi Pudjiastuti is the Ministry of Maritime Affairs and Fisheries.

2. She reads Harry Potter books every day.

3. They watch new movies every Sunday.

\section{Activity 7. Completing the Sentences}

Complete the sentences below.

1. She goes (go) Museum Angkut every Sunday.

2. They .... (watch) some property in Museum Angkut.

3. Rina .... (is) the Visitor the Museum Angkut.

4. Devan ... (is) the Ticket Keeper in Museum Angkut.

5. They .... (arrive) at Museum Angkut this morning.

\section{Simple Present Tense Negative}

To form negative simple present tense sentences, usually use the addition of don't or doesn't before the verb, except To Be and Modal. 
$S+$ Don't $^{\prime}$ /Doesn't + Verb (1) $+O$

If the verb is in the form of $\mathbf{T o} B \boldsymbol{B}$, then the formula becomes

$\mathrm{S}+($ is, am, are $)+$ not $+\mathrm{O}$

Examples of negative simple present tense:

- Susi Pudjiastuti is not the Ministry of Maritime Affairs and Fisheries.

- She doesn't read Harry Potter books every day.

- They don't watch new movies every Sunday

*Notice, for the third form subject (she, he it), after the word don't or doesn't, the verb form is not added s/es.

\section{Activity 8. Forming Negative Sentences}

Change these five sentences below into negative sentences!

1. Nina visits the Angkut Museum.

Answer :

2. They look to the Signboard. Answer :

3. Museum Angkut is the largest museum in Indonesia. Answer :

4. Dino looks at the vehicles at the Museum Angkut. Answer :

5. They go to Museum Angkut by Bus. Answer :

\section{Simple Present Tense: Interrogative}

To form interrogative sentences / question sentences, usually use the addition of do or does in front of the sentence.

\section{Do / Does + S + Verb $1+$ O}

The word do is used when the subject is I, you, they, or we. However, the word does is used if the subject is in the third person (She, He, It).

Examples of simple present tense interrogative:

1. Does she read a Harry Potter book?

2. Do they watch a new movie every day?

3. Do you play basketball every morning? 